\title{
En mann i 60-årene med akutte ryggsmerter og nyresvikt
}

\author{
En tidligere stort sett frisk mann ble lagt inn på en kommunal øyeblikke- \\ lig hjelp-avdeling på grunn av akutte ryggsmerter. Årsaken skulle vise \\ seg å være langt mer alvorlig enn først antatt. Kasuistikken viser hvor \\ viktig godt samarbeid mellom primær- og spesialisthelsetjenester er.
}

En mann i 60-årene som bodde alene ble fraktet med ambulanse til legevakten på grunn av akutte ryggsmerter. Han var svært palpasjonsøm i høyre side av abdomen. Det var normale funn ved perifer nevrologisk undersøkelse. Han var afebril, blodtrykket var 120/60 mm Hg og pulsen 78 slag/min. EKG var normalt. Blodprøver viste leukocytose på 20,9 $10^{9} / \mathrm{l}\left(4-11 \cdot 10^{9} / \mathrm{l}\right)$ og CRP 59 $\mathrm{mg} / \mathrm{l} /<5 \mathrm{mg} / \mathrm{ll}$. Ambulansepersonellet rapporterte at boligen hans var preget av dårlige hygieniske forhold. Legevaktlegen la inn pasienten på en kommunal øyeblikkelig hjelp-avdeling for videre utredning.

Akutte ryggsmerter er en svært vanlig tilstand. Omtrent halvparten av befolkningen i Norge har hatt smerter i korsryggen i løpet av det siste året (1). Det er internasjonal enighet om å dele korsryggssmerter $\mathrm{i}$ tre grupper: uspesifikke korsryggssmerter, korsryggssmerter med nerverotaffeksjon og korsryggssmerter med mulig alvorlig underliggende patologi eller nevrologisk akuttilfelle (2). Vår pasient hadde smerter som ble oppfattet å tilhøre den første gruppen. Ryggsmerter som stammer fra bevegelsesapparatet kan enkelte ganger være vanskelig å skille fra andre typer smerter som for eksempel viscerale smerter. Sykdom i indre organer kan gi refererte smerter i korsryggen. Listen over differensialdiagnoser for ryggsmerter er lang og inkluderer brudd, cancer, inflammatoriske lidelser, pankreatitt, pyelonefritt og mange flere (2).

I de norske kliniske retningslinjene for korsryggsmerter er det pekt på flere faktorer som indikerer mulig alvorlig underliggende patologi, såkalte «røde flagg». Ryggsmerter som debuterer etter 55 års alder er én av disse (2). Ved korsryggsmerter og tilstedeværelse av ett eller flere røde flagg bør klinikere være ekstra oppmerksom på mulig bakenforliggende, alvorlig sykdom.

Pasienten ble undersøkt av avdelingens lege dagen etterpå. Han var i god allmenntilstand og vitale parametere var uendret. Bortsett fra ryggsmertene var somatisk status upåfallende. Innleggende lege hadde ordinert paracetamol og tramadol ved behov som smerte- lindring. Han var ikke godt nok smertelindret med dette, og det ble ordinert paracetamol $1000 \mathrm{mg} \times 4 \mathrm{og}$ tramadol $50 \mathrm{mg} \times 3$ fast samt ved behov. Det ble ikke startet med ikkesteroide antiinflammatoriske midler (NSAID) grunnet tidligere perforert ulcus.

Pasienten hadde ikke utslett som kunne tyde på systemisk sykdom. Han fortalte at han den siste måneden hadde fått gradvis innsettende urininkontinens og brukte bleie, men sa at han ikke hadde oppsøkt lege av den grunn. Han var alkoholavholdende. CRP hadde falt til $40 \mathrm{mg} / \mathrm{l}$ og leukocytter til 16,9 109/l. Hemoglobin var 10,6 g/dl $(13,0-17,0 \mathrm{~g} / \mathrm{dl})$, og anemien var normocytær og normokrom. Urinstiks viste leukocytter 3+, blod 3+, protein 4+, nitritt negativ. Blæreskanning viste 200-400 $\mathrm{ml}$ urin i blæren til tross for at det stadig rant blank urin i bleien.

Det ble innhentet journalopplysninger fra pasientens fastlege, der han sist hadde vært 1,5 måned tidligere på grunn av en bekymringsmelding fra pårørende. Han hadde da benektet at han hadde noen plager. Det hadde vært normal somatisk status bortsett fra kreatinin på $323 \mu \mathrm{mol} / \mathrm{l}$ (60-105 $\mu \mathrm{mol} / \mathrm{ll}$. Fastlegen mistenkte nyrekreft som årsak og hadde derfor henvist pasienten til CT abdomen. Denne henvisningen ble avvist fordi nyrekreft sjelden gir akutt nyresvikt og fordi det ikke var kliniske opplysninger som underbygde diagnosen nyrekreft. Radiologen anbefalte at pasienten raskt ble henvist til nefrolog for videre utredning. Fastlegen valgte to uker senere å henvise pasienten til urolog i stedet. Omtrent én uke senere tok urolog kontakt med nefrolog da henvisningen var blitt liggende hos urologene. Nefrologen ringte så pasienten og ba han kontakte fastlegen for å få tatt nye nyrefunksjonsprøver. Tre dager senere ble pasienten innlagt $i$ kommunal øyeblikkelig hjelp-avdeling. De etterlyste blodprøvene var ennå ikke tatt. Den første dagen på avdelingen ble sykehusinnleggelse vurdert, men siden han var i god allmenntilstand og forrige kreatininverdimåling var over én måned gammel, bestemte man seg i første omgang for å rekvirere blodprøver for utredning av nyresvikten samt innhente anamnestiske opplysninger fra pårørende.

\section{Steinar Konradsen}

steinarkonradsen@yahoo.no

Intermediæravdelingen

Distriktsmedisinsk senter Midt-Troms

Tommy Mathisen

Sergio Haro

Avdeling for urologi og endokrin kirurgi

Universitetssykehuset Nord-Norge

Tromsø 


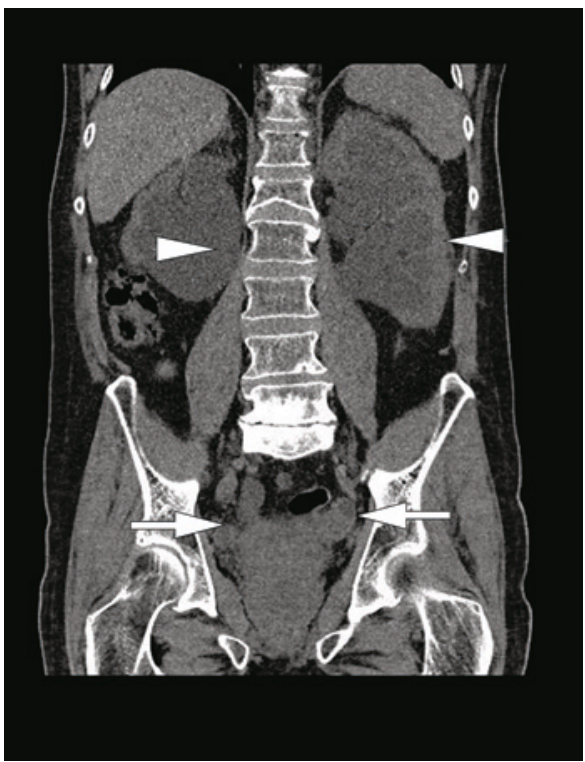

Figur 1 CT urinveier uten kontrast. Frontal projeksjon som viser massiv bilateral hydronefrose og bilateral hydroureter (piler). Man ser også forandringer $i$ distale ureter. Disse ble utredet nærmere med MR (se fig 3)

Ved samtale med pårørende kom det frem at pasienten var tidligere frisk med unntak av at han for syv år siden var laparotomert to ganger på grunn av perforert ulcus. De fortalte om en markert kognitiv endring etter denne operasjonen. Han fikk redusert hukommelse, neglisjerte $i$ større grad egen hygiene og fikk problemer med å skille fantasi fra virkelighet. Det siste halve året hadde alle disse endringene økt på. Pårørende hadde i tillegg merket at han hadde begynt å få problemer med uttale av enkelte ord og at han måtte lete etter ordene. De fortalte også at pasienten hadde bemerket at han ved enkelte anledninger hadde hatt synlig blod i urinen.

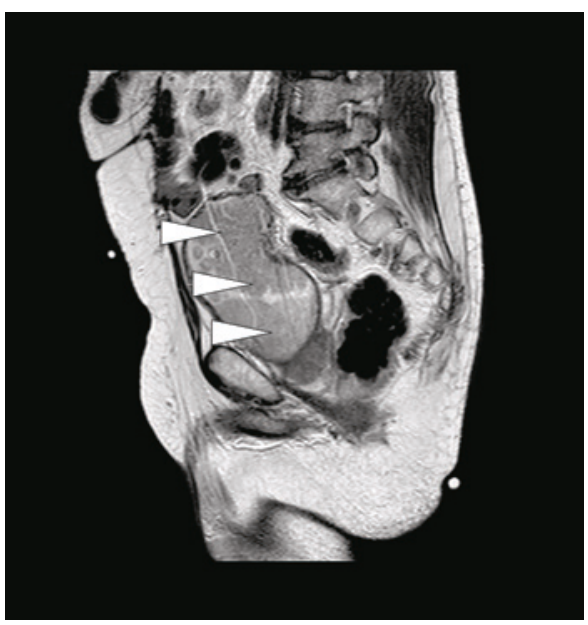

Figur 2 MR bekken (T2-vektet) i sagittal projeksjon med blæretumor (piler)
Det ble klart at pasienten hadde flere problemer: Nyresvikt og kognitiv svikt. Pasienten hadde ikke tegn til dehydrering og hadde ikke brukt nyretoksiske medikamenter eller nylig vært kritisk syk. På bakgrunn av lang varighet og makroskopisk hematuri ble dermed postrenal årsak med overløpsinkontinens (overflow) vurdert som mest sannsynlig. En mulig forklaring på kognitiv svikt kunne være en eventuell hypoksisk hjerneskade i forbindelse med et komplisert postoperativt forløp etter operasjon for perforert ulcus syv år tidligere.

Ved ny samtale med pasienten dag $2 \mathrm{kom}$ det frem at han over flere måneder hadde hatt nedsatt appetitt og vekttap. Han fortalte at han var mye trist og energiløs. Dette relaterte han til familiære problemer. Nevrologisk undersøkelse var uten patologiske funn. Det ble ikke utført noen systematisk kognitiv vurdering på dette tidspunktet. Differensialdiagnostisk ble alvorlig depresjon vurdert som mulig årsak til vekttap og nedsatt evne til egenomsorg, men i lys av andre somatiske funn ble ikke dette tillagt stor vekt.

Dag 2 var laboratorieprøvene som var sendt til analyse ennå ikke besvart. CRP- og leukocyttverdier holdt seg stabile. På UriCult var det ved inspeksjon sparsom vekst av ulike grampositive bakterier. Dette ble tolket som blandingsflora. Prøven ble sendt til videre analyse. Senkningsreaksjonen var $50 \mathrm{~mm} / \mathrm{t} /<20 \mathrm{~mm} /$ t). Forsøk på å legge inn transuretralt kateter mislyktes pga. obstruksjon i blærehalsområdet. CT nyre/urinveier uten kontrast utført lokalt ble vurdert, men ikke rekvirert, da man regnet med å måtte gjøre en bredere kartlegging på sykehus senere i forløpet. Pasienten ble fortløpende vurdert for innleggelse på sykehus, men holdt seg klinisk og laboratoriemessig stabil til dag 3. Laboratorieprøver viste da hemoglobin $10,1 \mathrm{~g} / \mathrm{dl}$, SR $53 \mathrm{~mm}$, leukocytter $15,8 \cdot 10^{9} / \mathrm{l}$, natrium $134 \mathrm{mmol} / \mathrm{l}(137-145$ $\mathrm{mmol} / \mathrm{l})$, kalium 4,5 mmol/l $(3,6-4,6 \mathrm{mmol} / \mathrm{l})$, kreatinin $469 \mu \mathrm{mol} / \mathrm{l}$, estimert glomerulær filtrasjonsrate (GFR) $11 \mathrm{ml} / \mathrm{min} / 1,73 \mathrm{~m}^{2}(>90 \mathrm{ml}$ $\left.\mathrm{min} / 1,73 \mathrm{~m}^{2}\right)$, urinstoff $39,4 \mathrm{mmol} / \mathrm{l}(3,5-8,1$ $\mathrm{mmol} / \mathrm{ll}$ og CRP $40 \mathrm{mg} / \mathrm{l}$. Pasienten ble dermed innlagt $i$ sykehus på grunn av økende nyresvikt.

Like etter innleggelse ble det tatt CT urinveier uten intravenøs kontrast (fig 1). Denne viste bilateral uttalt hydronefrose og hydroureter med moderat atrofi av nyreparenkym. Det var forstørret urinblære med høyattenuerende innhold som ved blod. Cystoskopi ble gjort akutt og viste at blæren var fylt av koagler og papillomatøse tumorforandringer. Disse ble biopsert. Hematurikateter og bilaterale nefrostomikatetre ble anlagt. Biopsiene viste høygradig urotelialt karsinom, pT1GIII. Det ble ikke sett muskulatur. MR bekken viste uttalte tumorforandringer i nærmest hele blæren med innvekst i prostata og begge urinledere. Den viste også gjennombrudd av muscularis propria som ved minst T3-stadiet med muskelinvasiv blærecancer (fig 2, fig 3). For øvrig var det normale funn uten organmetastaser eller forstørrede lymfeknuter. Skjelettscintigrafi viste ikke tegn til metastaser. Ved nevropsykologisk testing fant man en sannsynlig mild kognitiv svik som ble planlagt fulgt opp etter utskrivning. Nyrefunksjonen bedret seg noe ved hjelp av avlastningen, og kreatininverdien stabiliserte seg rundt $190 \mu \mathrm{mol} / \mathrm{l}$.

Pasienten ble operert med cystoprostatouretrektomi med transuretero-ureterokutaneostomi og utvidet iliakalt glandeltoilette. Det ble ikke anlagt Bricker-deviasjon med urostomi. Dette for å unngå forverring av nyresvikten samt for å unngå intraabdominal tarmanastomose.

Histologi av preparatet viste at tumoren var $10 \mathrm{~cm}$ stor og fylte hele blæren med festepunkter i blæretaket, blæregulv og høyre og venstre blærevegg. Det var infiltrasjon i prostata, men ingen lymfeknutemetastaser. Tumor besto av høygradig papillært urotelialt karsinom, patologisk stadium T4aNO.

Under oppholdet ble nefrostomiene og ureterstentene fjernet etter at man ved ureteroskopi ikke visualiserte noen strikturer.

Etter utskrivning har den kognitive funksjonen bedret seg. Han er stort sett selvhjulpen i hverdagen og har førerkort klasse $B$. Ved kontroller har det ikke vært tegn til residiv av blærekreften.

\section{Diskusjon}

Akutt nyresvikt er en vanlig årsak til sykehusinnleggelse og har en antatt insidens på 2-3/1 000 personer/år. Tilstanden kan være svært alvorlig, og det er rapportert mortalitet på 25-80\% avhengig av årsaken og pasientens tilstand (3).

Årsakene til akutt nyresvikt deles inn i tre kategorier: Prerenale, renale og postrenale årsaker. Prerenal nyresvikt skyldes redusert perfusjonstrykk til nyren, som oftest betinget i hypovolemi. En renalt betinget nyresvikt kan ha mange årsaker, men de vanligste er akutt tubulær nekrose på iskemisk eller toksisk grunnlag. Glomerulonefritt og ateroembolisk sykdom kan også forårsake renalt betinget nyresvikt. Vår pasient hadde en postrenal nyresvikt. Denne typen nyresvikt er forårsaket av obstruksjon i urinveiene. Den vanligste årsaken hos eldre menn er prostatahypertrofi. Tidlig diagnose og rask behandling av postrenal nyresvikt er forbundet med forbedret nyrefunksjon hos de fleste pasienter (3).

Den kliniske presentasjonen av postrenal nyresvikt varierer med årsak og alvorlighetsgrad av nyresvikten. En del pasienter er asymptomatiske og identifiseres ved måling 


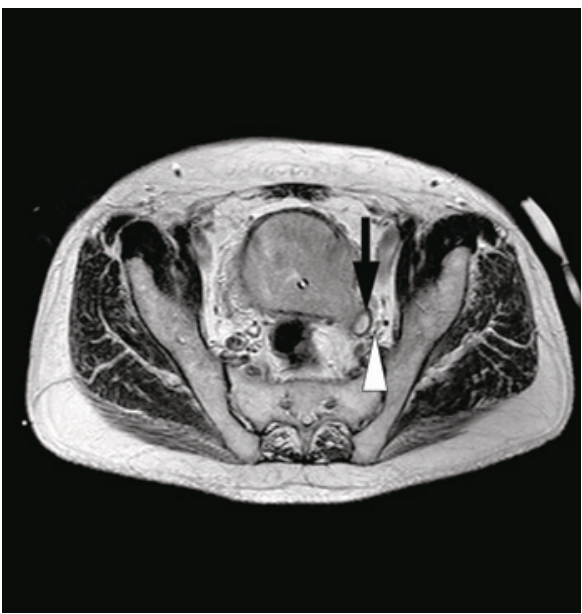

Figur 3 MR bekken (T2-vektet) i aksial projeksjon som viser blæretumor med gjennombrudd av blærens muscularis propria som ved minst stadium T3 (hvit trekant). Bildet viser også dilatert venstre ureter pga. tumorinnvekst (svart pil)

av nyrefunksjonen. Alvorlig nyresvikt gir vanligvis symptomer som slapphet, konfusjon, nedsatt appetitt, kvalme og/eller ødemer. Oliguri eller anuri er også mulige presentasjonsformer (3). Vår pasient hadde utviklet økende grad av kognitiv svikt, og dette var trolig forårsaket av uremisk encefalopati kombinert med en mulig bakenforliggende kognitiv svikt som antas å ha oppstått i forbindelse med perforert ulcus flere år tidligere.

Kasuistikken er illustrerende for hvor viktig et godt samarbeid mellom primær- og spesialisthelsetjenesten er for gode pasientforløp. Pasienter med akutt nyresvikt bør som regel umiddelbart legges inn i sykehus $(3,4)$. Allmennlegens CT-henvisning ble avslått og sendt $\mathrm{i}$ retur fordi $\mathrm{CT}$ abdomen ikke var riktig modalitet for utredning av nyresvikt samt at henvisningen heller ikke inneholdt opplysninger som bygde oppunder mistanken om nyrekreft. Ultralyd av nyrer og urinveier er førstevalg ved radiologisk utredning av akutt nyresvikt (5). Allmennlegen sendte henvisning til urologisk poliklinikk, men pga. mangelfulle kliniske opplysninger ble denne henvisningen oversendt til nefrologisk avdeling.

I allmennpraksis bør man hos pasienter med uforklarlig høye kreatininverdier aktivt spørre etter symptomer som kan tyde på postrenal nyresvikt, slik som endret vannlatningsmønster eller nyoppstått inkontinens. Man bør også spørre om pasienten har hatt synlig blod i urinen, og man bør ta urinstiks. Grundig palpasjon og perkusjon over sym- fysen samt digital rektaleksplorasjon hører også med til primærundersøkelsene av en slik pasient. Slike opplysninger i en henvisning er helt nødvendige for riktig vurdering av adressat og hastegrad.

Kasuistikken illustrerer også hvor vanskelig det kan være å vurdere på hvilket omsorgsnivå pasienter bør innlegges. Svært få legevakter har i dag tilgang til journalsystemet til fastlegene. Legevaktlegen var ikke klar over at pasienten hadde utviklet urininkontinens over kort tid og kjente ikke pasientens kognitive funksjon eller evne til egenomsorg fra tidligere. Akutte ryggsmerter er en vanlig tilstand på norske legevakter, og på tross av bruken av «røde flagg» i behandlingsretningslinjer kan det tidlig i forløpet være vanskelig å identifisere pasienter med alvorlig, underliggende patologi. Legevaktarbeid preges av tidspress, samtidighetskonflikter, mangelfull informasjon om pasientens tidligere sykdommer og begrensede ressurser for diagnostikk. Disse faktorene bidrar til at risikoen for feilvurderinger er stor (6). Derfor bør legevaktleger være varsomme med å velge lavt omsorgsnivå for pasienter med potensielt alvorlige tilstander eller ved uklar diagnose. Vi har tidligere vist at risikoen for å bli overført til sykehus fra kommunal øyeblikkelig hjelp-avdeling er omtrent syv ganger større om det stilles feil diagnose av innleggende lege (7).

Det er vist at innleggende lege og mottagende lege på sykehus kan ha svært ulike vurderinger av hva som er det riktige behandlingsnivået for akutt innlagte pasienter (8). Det kan på innleggelsestidspunktet være vanskelig å velge ut de pasientene som kan ha nytte av kommunale akuttilbud. Med økende tilgjengelighet av kommunale øyeblikkelig hjelp-avdelinger er det grunn til å se nærmere på hvordan legevaktarbeidet bør organiseres.

Manglende informasjon om tidligere utredning medførte forsinket diagnostikk og behandling av vår pasient. Det er liten grunn til å tro at dette er et enkelttilfelle. God informasjonsutveksling mellom journalsystemene i sykehus og kommunale øyeblikkelig hjelp-sengeposter er en forutsetning for sikker pasientbehandling. Pasientjournalloven $\S 9$ åpner for virksomhetsovergripende journalsystem (9), men svært få kommuner og sykehus har avtaler om dette. For å bedre sikkerheten for pasienter som behandles $i$ kommunehelsetjenesten bør kommunene og sykehusene ta i bruk denne muligheten.

Pasienten har gitt samtykke til at artikkelen blir publisert.
Vi vil takke overlege Gunnar Oltmanns ved Radiologisk avdeling, Universitetssykehuset Nord-Norge, Troms $\emptyset$, for innspill vedrørende bildediagnostikk.

\section{Steinar Konradsen (f. 1981)}

er lege i spesialisering i allmennmedisin. Forfatter har fylt ut ICMJE-skjemaet og oppgir ingen interessekonflikter.

\section{Tommy Mathisen (f. 1976)}

er cand.med. og konsulent.

Forfatter har fylt ut ICMJE-skjemaet og oppgir ingen interessekonflikter.

\section{Sergio Haro (f. 1957)}

er spesialist i generell kirurgi og i urologi og er overlege.

Forfatter har fylt ut ICMJE-skjemaet og oppgir ingen interessekonflikter.

\section{Litteratur}

1. Lærum E, Brage S, Ihlebæk C et al. Et muskelog skjelettregnskap. Forekomst og kostnader knyttet til skader, sykdommer og plager i muskelog skjelettsystemet. Oslo: Formidlingsenheten for muskel-og skjelettlidelser, 2007. www.formi.no (5.2.2015).

2. Lærum E, Brox JI. Storheim K. red. Nasjonale kliniske retningslinjer. Korsryggsmerter - med og uten nerverotaffeksjon. Oslo: Formidlingsenheten for muskel-og skjelettlidelser/Sosial- og helsedirektoratet, 2007. www.formi.no (5.2.2015)

3. Rahman M. Shad F. Smith MC. Acute kidney injury: a guide to diagnosis and management. Am Fam Physician 2012; 86: 631-9

4. National Institute of Clinical Excellence. Acute kidney injury. Prevention, detection and management of acute kidney injury up to the point of renal replacement therapy. www.nice.org.uk/Guidance/ CG169 (1.11.2015).

5. Remer EM, Papanicolaou N, Casalino DD et al. ACR Appropriateness Criteria[ $(\mathbb{R})$ on renal failure. Am J Med 2014; 127: 1041-8.e1.

6. Helsetilsynet. Kommunale legevakter - Helsetilsynets funn og vurderinger. www. helsetilsynet.no/ no/Publikasjoner/Brev-hoeringsuttalelser/ Utvalgte-brev-og-horingsuttalelser-tidligere-ar/ Kommunale-legevakter-Helsetilsynets-funnvurderinger/ (5.1.2016).

7. Konradsen S, Abelsen B. Erfaringer med kommunale øhjelpsenger i distrikts-Norge. Utposten 2014; 5: 16-9

8. Eikeland G, Garåsen H, Jacobsen G. Finnes det alternativer til øyeblikkelig hjelp-innleggelser? Tidsskr Nor Lægeforen 2005; 125: 2355-7.

9. LOV-2014-06-20-42. Lov om behandling av helseopplysninger ved ytelse av helsehjelp (pasientjournalloven). https://lovdata.no/dokument/NL/lov/ 2014-06-20-42?q=pasientjournalloven (5.1.2016)

Mottatt 14.4. 2015, første revisjon innsendt 10.6. 2015, godkjent 10.12.2015. Redaktør: Liv-Ellen Vangsnes. 